\title{
PEMBINAAN KEISLAMAN BAGI ANGGOTA DAN PNS POLRI DI KEPOLISIAN DAERAH JAWA BARAT
}

\author{
Bella Moriska, * \\ Udin Supriadi, Toto Suryana \\ Program Studi Ilmu Pendidikan Agama Islam, \\ Fakultas Pendidikan Ilmu Pengetahuan Sosial, Universitas Pendidikan Indonesia \\ *Email:moriskabella@gmail.com
}

\begin{abstract}
ABSTRAK
Penelitian ini tentang pembinaan keislaman di Kepolisian Daerah Jawa Barat. Penelitian ini bertujuan untuk mengetahui gambaran umum pembinaan keIslāman yang ada di Kepolisian Daerah Jawa Barat. Penelitian ini menggunakan pendekatan kualitatif, lokasi penelitian bertempat di Markas Kepolisian Daerah Jawa Barat yang beralamat di Jl. Soekarno-Hatta No. 748 Bandung, Jawa Barat 40000, Indonesia. Pengumpulan data dilakukan dengan teknik observasi, wawancara, studi dokumentasi, dan disempurnakan dengan triangulasi. Hasil yang diperoleh dalam penelitian ini adalah (1) Pembinaan keIslāman didirikan atas perintah Kepala Kepolisian Republik Indonesia berupa surat perintah yang berbentuk telegram mengenai optimalisasi giat pembinaan mental, (2) Program pembinaan keIslāman ini terbagi ke dalam tiga bagian, yaitu pembinaan rohani Islām harian, pembinaan rohani Islām mingguan dan pembinaan rohani Islām hari besar, (3) Pelaksanaan Pembinaan keIslāman dibagi menjadi tiga bagian yaitu pelaksanaan pembinaan rohani Islām harian berupa kegiatan kuliah tujuh menit rutin setelah ba' da żuhur, pelaksanaan pembinaan rohani Islām mingguan mingguan berupa kegiatan kajian rutin yang dilaksanakan setiap hari kamis setelah apel pagi, dan pelaksanaan pembinaan rohani Islām pada hari-hari besar Islām dilaksanakan ketika hari jum'at dan hari-hari besar Islām lainnya, (4) Faktor pendukung kegiatan pembinaan keIslāman diantaranya adalah support dari pimpinan berupa ketauladanan dan faktor penghambat kegiatan ini adalah pekerjaan yang tidak menentu dari masing-masing anggota, serta tidak adanya sanksi dan tekanan dari pemimpin membuat kesadaran mereka semakin berkurang, (5) Hasil dari pembinaan ialah semakin berkurangnya anggota dan PNS Polri di Kepolisian Daerah Jawa Barat yang melakukan penyimpangan atau melanggar kode etik.
\end{abstract}

Kata Kunci: Penyimpangan, Anggota dan PNS, Pembinaan keIslāman 


\section{PENDAHULUAN}

Gangguan keamanan, ketertiban dan kriminalitas merupakan gejala sosial yang normal dan sering terjadi di masyarakat. Bahkan telah menjadi kebiasaan bagi para pelanggar untuk terus melakukan hal yang dapat mengganggu masyarakat. Oleh karena itu, perlu adanya pengamanan untuk mengatasi gangguan-gangguan yang dapat merugikan masyarakat tersebut.

$\begin{array}{ccc} & \text { Pemeliharaan keamanan dalam } \\ \text { negeri } & \text { dilaksanakan } & \text { melalui }\end{array}$
penyelenggaraan fungsi kepolisian yang merupakan fungsi pemerintahan negara di bidang keamanan dan ketertiban masyarakat, penegakan hukum dan perlindungan, pengayoman, serta pelayanan kepada masyarakat. Sesuai ketentuan konstitusi, penyelenggaraan keamanan dalam negeri dilaksanakan melalui sistem keamanan yang bersifat menyeluruh dengan Polri sebagai kekuatan utama dengan melibatkan masyarakat sebagai pendukung (Lihawa \& Mustofa , 2010, hlm. 1).

Sebagai negara demokrasi maka penyelenggaraan fungsi kepolisian harus didasarkan pada prinsip-prinsip pemolisian demokratis yang terutama ditandai dengan akuntabilitas, transparansi, dan perlindungan hak asasi manusia. Prinsip ini akan melahirkan sebuah keamanan yang terjamin bagi masyarakat serta pemerintahan dalam suatu negara. Untuk menanggulangi gangguan keamanan, ketertiban, serta kriminalitas yang mungkin timbul, maka diperlukan penyelenggaraan fungsi kepolisian yang handal dan mempunyai daya cegah yang tinggi (Lihawa \& Mustofa , 2010, hlm. 2-3).

Secara fungsional polisi dituntut untuk melaksanakan tugas dengan sikap etis, adil dan ramah, serta memberikan layanan dan menjaga ketertiban. Tetapi akhir-akhir ini masyarakat sudah mulai kehilangan kepercayaan kepada polisi mengenai kinerja yang dilakukan oleh polisi. Terkait dengan penindakan yang bersikap tidak etis, adil dan ramah, bahkan menggunakan kekuatan institusi untuk melakukan kekerasan.

Kunarto (1997a, hlm. 11) menjelaskan bahwa lahirnya citra buruk atau kegagalan pelaksanaan tugas polisi, berawal dari penyimpangan etika atau tidak memegang teguh kode etik. Dalam berbagai literatur, penyimpangan kode etik disebut juga sebagai perbuatan yang tidak berakhlak, yang dilingkup kepolisian universal diidentifikasikan sebagai perbuatan-perbuatan tidak jujur, kekerasan yang kejam, penerimaan hadiah, penahanan ilegal, penggeledahan yang tidak sah dan perilaku yang tidak sopan.

Pada penyimpangan polisi, dengan menyalahgunakan wewenang yang dimiliki akan mendorong terjadinya pemudaran wibawa polisi. Memudarnya wibawa polisi akan mengarah kepada suatu ketidak stabilan keamanan, yang bukan tidak mungkin akan mendorong tindakan anarkis. Memudarnya wibawa polisi ini sama artinya menyeret kembali Polri kembali ke dalam situasi yang tidak menguntungkan, bahkan akibat penyimpangan yang dilakukan oleh oknum polisi dapat mengakibatkan dampak kekerasan bagi masyarakat.

Kunarto (1994, hlm. 6) mendefinisikan kekerasan polisi sebagai semua bentuk pemakain kekuatan fisik (termasuk kekuatan yang mematikan) baik yang dibenarkan maupun yang tidak dibenarkan terhadap masyarakat. Friedrich (dalam Kunarto, 1994, hlm. 6) mendefinisikan kekerasan polisi dengan lebih khusus. Ia berpendapat bahwa kekerasan polisi adalah pemakaian kekuatan oleh polisi termasuk semua kegiatan yang menggunakan kekuatan, baik sah maupun tidak sah yang dapat menghasilkan kerugian fisik dan emosional.

Penyimpangan perilaku polisi merupakan gambaran umum tentang kegiatan petugas polisi yang tidak sesuai dengan wewenang resmi petugas, 
wewenang organisasi, nilai dan standar perilaku sopan (yang biasanya dilaksanakan, bukan dikatakan). Peyimpangan dapat mencakup banyak perilaku yang dapat dilakukan petugas (Kunarto, 1994, hlm. 4).

Penyimpangan-penyimpangan yang dilakukan oleh oknum polisi, mengindikasikan adanya kesenjangan antara kode etik polisi atau harapan bagaimana polisi seharusnya dengan realita yang ada dilapangan. Kesenjangan yang terjadi tentunya bukan tanpa sebab, menurut peneliti ada dua faktor yang menjadi penyebab terjadinya penyimpangan yaitu faktor dari dalam diri dan faktor dari luar. Faktor dari dalam diri diantaranya adalah ketidaksanggupan individu untuk menyesuaikan diri dengan tugas polisi yang diampu, keinginan untuk dipuji dan kondisi mental yang kurang sehat.

Sedangkan faktor dari luar diantaranya adalah kebutuhan ekonomi, lingkungan yang kurang baik dan kurangnya pemahaman tentang agama. Menurut peneliti sebab yang paling krusial adalah kurangnya pemahaman tentang agama.

Oleh karena itu, suatu tanggung jawab untuk meminimalisasi tindakantindakan penyimpangan polisi adalah dengan melakukan suatu pembinaan terhadap akhlak masing-masing pribadi polisi.

Pembinaan menurut Gafur (1978, hlm. 7) adalah upaya pendidikan yang dilakukan baik secara formal mapun non formal secara sadar, terarah dan bertanggung jawab dengan maksud mengembangkan kepribadian secara seimbang dan utuh agar menjadi pribadi yang mandiri. Sedangkan menurut Syarif (1991, hlm. xii) pembinaan adalah suatu proses untuk membantu seseorang untuk membentuk, meningkatkan dan mengubah pengetahuan, keterampilan sikap dan tingkah lakunya agar dapat mencapai standar tertentu.
Dengan demikian pembinaan merupakan upaya mengembangkan kepribadian seseorang melalui pendidikan yang dapat merubah sikap dan perilaku ke arah yang lebih baik. Pembinaan yang menjadi fokus dalam penelitian ini adalah upaya mengembangkan kepribadian melalui pembinaan keIslāman.

Pembinaan keIslāman diarahkan untuk memperkuat keyakinan para polisi. Arifin (1985, hlm. 25) berpendapat bahwa pembinaan keIslāman bisa dikatakan juga sebagai bimbingan konseling islami. Namun, menurutnya pembinaan keIslāman atau bimbingan konseling islami di negara kita belum diterapkan. Oleh karena itu kegiatan pembinaan keIslāman ini harus dilakukan secara mandiri oleh lembaga, dalam ranah pendidikan tentunya yang berwenang melakukan pembinaan keIslāman adalah guru-guru pendidikan agama islam. Sedangkan dalam sebuah lembaga atau institusi tentunya yang berwenang melakukan pembinaan keIslāman adalah stack holder (pemangku kebijakan) yaitu pemimpinnya sendiri.

Dengan adanya pembinaan keIslāman, diharapkan dapat merubah perilaku-perilaku menyimpang para polisi kearah yang lebih baik. Serta dapat mengembalikan kepercayaan masyarakat yang sempat memudar pada satuan kepolisian.

\section{A. Pembinaan keIslāman}

Seorang pakar psikologi Islām, Zakiah Daradjat (2004, hlm. 35) menjelaskan bahwa pendidikan Islām dapat diartikan sebagai pendidikan yang seluruh aspeknya, mulai dari visi, misi, tujuan, proses belajar mengajar, pendidik, peserta didik, sarana prasarana, pembiayaan, pengelolaan, lingkungan, sampai evaluasi didasarkan pada ajaran Islām.

Dalam pembinaan keIslāman terdapat pendidikan Islām yang harus dimiliki seseorang agar tercipta kehidupan yang hakiki dan selalu berada pada jalan yang Allah ridhai. Seperti yang disampaikan oleh Jalaluddin (2003, hlm. 74) bahwa pendidikan Istām adalah usaha 
pembinaan dan pengembangan potensi manusia secara optimal sesuai dengan statusnya, dengan berpedoman kepada syari'ah Islām yang disampaikan oleh rasūl Allāh agar manusia dapat berperan sebagai pengabdi Allāh yang setia dengan segala aktivitasnya agar tercipta suatu kondisi kehidupan Islām yang ideal, selamat, aman, sejahtera, berkualitas, dan memperoleh jaminan kesejahteraan hidup di dunia dan akhirat.

Dalam pendidikan Islām terdapat suatu pembinaan atau bimbingan yang mengarahkan manusia kepada jalan yang sebenarnya, yaitu jalan yang menuju pada Allāh Swt..

Arifin (1985, hlm.25) mengungkapkan bahwa pembinaan atau bimbingan Islām ialah kegiatan yang dilakukan oleh seseorang dengan maksud memberikan bantuan kepada orang lain yang mengalami kesulitan rohaniyah dalam hidupnya agar orang tersebut mampu mengatasinya sendiri karena timbul kesadaran atau penyerahan diri terhadap kekuasaan Tuhan.

Arifin (1985, hlm. 25) berpendapat bahwa pembinaan keIslāman dapat dikatakan juga sebagai bimbingan konseling Islāmi. Namun, menurutnya pembinaan keIslāman atau bimbingan konseling Islāmi di negara kita belum diterapkan. Oleh karena itu kegiatan pembinaan keIslāman ini harus dilakukan secara mandiri oleh lembaga, dalam ranah pendidikan tentunya yang berwenang melakukan pembinaan keIslāman adalah guru-guru pendidikan agama Islām. Sedangkan dalam sebuah lembaga atau institusi tentunya yang berwenang melakukan pembinaan keIslāman adalah stack holder (pemangku kebijakan) yaitu pemimpinnya sendiri.

\section{B. Pembinaan Rohani Bagi Aparat Pemerintahan}

Dalam Kamus Besar Bahasa Indonesia mengartikan kata polisi dengan: a. badan pemerintahan yang bertugas memelihara keamanan dan ketertiban umum (menangkap orang yang melanggar hukum dan sebagainya, b. Anggota badan pemerintahan (pegawai Negara yang bertugas menjaga keamanan) (Kunarto, 1997b, hlm. 53).

Menurut Baihaki (2009, hlm. 40) di Italia polisi disebut politeia, sedangkan di perancis disebut la polic, di Belanda disebut dengan Politie. Indonesia mengikuti tradisi Belanda dengan menyebutnya dengan kata Polisi atau Politie.

Para cendikiawan menyimpulkan bahwa terdapat tiga pengertian polisi yaitu, polisi sebagai fungsi, polisi sebagai organ kenegaraan dan polisi sebagai pejabat atau petugas. Namun yang sering disebut dalam kehidupan sehari-hari adalah polisi sebagai pejabat atau petugas, hal ini menyebabkan polisi dan masyarakat harus dibedakan agar masyarakat jelas bahwa pada polisilah rakyat dapat meminta perlindungan dan mengadukan keluhan (Kunarto, 1997b, hlm. 56).

1. Fungsi dan Tugas Kepolisian

Kepolisian menurut Baihaki (2009, hlm. 37) tumbuh dan berkembang bersamaan dengan tumbuh dan berkembangnya peradaban manusia. Setiap peradaban manusia yang memulai dan merasakan perlunya keamanan, ketentraman, dan mempertahankan kehidupannya, pada saat itulah sebenarnya fungsi polisi itu ada, tumbuh dan berkembang.

Fungsi polisi itu tumbuh dan berkembang semakin jelas manakala ancaman terhadap kelompok itu semakin nyata. Ancaman itu bukan hanya berupa bahaya yang datang dari luar kelompok itu, namun ancaman juga dapat berasal dari dalam kelompoknya (Baihaki, 2009, hlm. 37).

Salah satu tugas kepolisian menurut Baihaki (2009, hlm. 30) adalah kehadiran polisi di tengah masyarakat, karena kehadiran polisi tidak dapat digantikan dengan teknologi secanggih apapun. Tugas polisi yang mencangkup tugas perlindungan, pengayoman dan pelayanan 
di samping tugasnya sebagai penegak hukum, polisi juga bertugas untuk memelihara ketertiban dan pelayanan sosial di masyarakat.

\section{Kode Etik Polri}

Polri memiliki kode etik yang harus di patuhi oleh setiap personil. Kunarto (1997a, hlm. 4) memberikan penjelasan bahwa etika adalah ilmu dan pengetahuan tentang perilaku manusia yang terkait dengan norma nilai-nilai atau ukuran buruk baiknya yang berlaku pada masyarakat. Sedangkan etika kepolisian adalah norma tentang perilaku polisi untuk dijadikan pedoman dalam mewujudkan pelaksanaan tugas yang baik bagi penegakan hukum, ketertiban umum dan keamanan masyarakat.

Untuk melahirkan kode etik Polri Tri Brata menurut Djoko Soetono (dalam Kunarto, 1997b, hlm. 107) tidaklah mudah bahkan studinya sampai dilakukan di Belanda dengan waktu yang relatif lama. Selain itu diskusi-diskusi yang dilakukan di tanah air bersama para pakar dan guru besar Universitas Indonesia dan Perguruan Tinggi Ilmu Kepolisian (PTIK) prosesnya cukup alot.

3. Penyimpangan Etika di Lingkungan Kepolisian

Penyimpangan menurut Kamus

Besar Bahasa Indonesia (2008, hlm. 1047) adalah perilaku yang tidak sesuai dengan nilai-nilai kesusilaan atau kepatutan baik dalam sudut pandang kemanusiaan atau agama.

Menurut Kunarto (1994, hlm. 4) penyimpangan perilaku polisi merupakan gambaran umum tentang kegiatan petugas polisi yang tidak sesuai dengan wewenang resmi petugas, wewenang organisasi, nilai dan standar perilaku sopan. Peyimpangan dapat mencakup banyak perilaku yang dapat dilakukan petugas.

Menurut Kunarto (1997a, hlm. 3) bahwa dalam mengamalkan kode etik atau suatu ajaran biasanya melalui proses; mengerti, memahami, menghayati, mengamalkan, yang merupakan urutan yang tidak boleh diputar balikan. Para senior Polri banyak yang berpendapat bahwa Kode Etik Polri itu dimasa sekarang ini baru sampai tahap dimengerti oleh sebagian besar warga Polri. Karenanya dapat dimengerti jika secara umum perilaku mereka itu tidak bersifat etis, yang menyebabkan merebaknya kegagalan dalam pelaksanaan tugas. Banyaknya tindakan kekerasan, penyalahgunaan wewenang dan lain-lain, yang menyebabkan meluasnya kecaman serta merosotnya citra Polri merupakan bukti dari konstatasi (hak untuk menetapkan gejala atau tanda-tanda di suatu keadaan) tersebut.

\section{METODE}

\section{A. Desain Penelitian}

Peneliti menggunakan desain penelitian deskriptif serta menggunakan metode studi kasus. Tahap persiapan dilakukan peneliti dengan mengunjungi markas Kepolisian Daerah Jawa Barat yaitu sebagai tempat dilaksanakannya pembinaan keIslāman untuk mengajukan izin pra penelitian dan penelitian. Setelah peneliti mengajukan izin penelitian kepada sekretaris umum Kepolisian Daerah Jawa Barat, satu minggu kemudian peneliti mendapatkan kabar dari pengurus pembinaan keIslāman bahwa peneliti diperbolehkan melakukan penelitian di markas Kepolisian Daerah Jawa Barat. Peneliti mengetahui adanya kegiatan pembinaan keIslāman di markas Kepolisian Daerah Jawa Barat dari seorang kerabat yang berstatus anggota kepolisian.

\section{B. Tempat Penelitian dan Partisipan}

Lokasi penelitian bertempat di Markas Kepolisian Daerah Jawa Barat yang beralamat di Jl. Soekarno-Hatta No. 748 Bandung, Jawa Barat 40000, Indonesia.

Partisipan penelitian dalam penelitian ini adalah orang-orang yang terlibat dalam pembinaan keIslāman di Kepolisian Daerah Jawa Barat, terutama orang yang mengetahui latar belakang terbentuknya program pembinaan keIslāman yang ada di Kepolisian Daerah 
Jawa Barat, yang termasuk pada subjek penelitian ini adalah ketua pembinaan keIslāman, pengurus pembinaan keIslāman, pemateri pembinaan keIslāman serta peserta pembinaan keIslāman yang ada di Kepolisian Daerah Jawa Barat.

\section{Pengumpulan Data}

Teknik pengumpulan data melalui wawancara, observasi, studi dokumentasi dan triangulasi. Untuk mendapatkan data yang diinginkan, maka dalam penelitian ini menggabungkan keempat macam teknik pengumpulan data tersebut agar data yang dihasilkan kredibel.

Peneliti memverifikasi sumber data dan metode dengan triangulasi, instrument penelitian pun diverifikasi dengan cara meminta bantuan orang lain untuk ikut membantu penelitian. Oleh sebab itu, peneliti meminta bantuan orang lain dalam proses pengumpulan data wawancara dan observasi. hal ini dilakukan agar data yang dihasilkan kredibel.

\section{Analisis Data}

Menurut Sucipto \& Arief (2010, hlm. 7) terdapat tiga jalur analisis data kualitatif yaitu reduksi data, penyajian data, dan penarikan kesimpulan. Proses ini berlangsung terus menerus selama penelitian berlangsung, bahkan sebelum data benar-benar terkumpul sebagaimana terlihat dari kerangka konseptual penelitian, permasalahan studi dan pendekatan pengumpulan data yang dipilih peneliti.

Peneliti melakukan analisis data sejak pertama kali memasuki lapangan ketika melakukan pra penelitian sampai dengan terakhir kali peneliti melakukan penelitian. Setelah melakukan analisis data peneliti melakukan reduksi data dan penyajian data secara termenerus selama penelitian berlangsung sampai akhirnya peneliti menarik kesimpulan.

\section{HASIL DAN PEMBAHASAN}

\section{A. Profil Pembinaan KeIslāman}

Pembinaan keIslāman di Kepolisian

Daerah Jawa Barat dimulai ketika Kepolisian Daerah Jawa Barat itu sendiri berada yaitu pada 1 Juli 1964. Awalnya markas Kepolisian Daerah Jawa Barat berada di Jalan Braga. Landasan didirikannya pembinaan keIslāman ini adalah telegram Kepala Kepolisian Republik Indonesia mengenai optimalisasi giat pembinaan mental.

Landasan tersebut kemudian ditindaklanjuti oleh Kepala Kepolisian Daerah Jawa Barat dengan surat telegram No. Pol. : ST/595/V2009 tanggal $15 \mathrm{Mei}$ 2009 tentang arahan Kapolda Jawa Barat, agar para Kastker dan Kasatwil di jajaran Polda Jawa Barat untuk mengoptimalkan kegiatan pembinaan rohani dan mental anggota.

Sesuai dengan pemaparan di atas bahwa landasan didirikannya pembinaan keIslāman di Kepolisian Daerah Jawa Barat berawal dari perintah Kapolri berupa surat perintah berbentuk telegram, kemudian perintah dari Kapolri ditindaklanjuti oleh Kapolda Jawa Barat dan terbentuklah pembinaan keIslāman. Hal ini mengidentifikasikan bahwa anggota dan PNS Polri menaati perintah pimpinan.

\section{B. Perencanaan Pembinaan KeIslāman}

Perencanaan pembinaan keIslāman yang ada di Kepolisian Daerah Jawa Barat dibuat berdasarkan pada Undang-undang Kepolisian Negara Republik Indonesia No. 2 Tahun 2002 dan Surat Telegram Kapolda Jabar No.Pol. : ST/595/V2009 tanggal 15 Mei 2009 tentang arahan Kapolda Jabar, agar para Kastker dan Kasatwil di jajaran Polda Jawa Barat untuk mengoptimalkan kegiatan pembinaan rohani dan mental anggota. Maksud dan tujuan dari dibuatnya perencanaan adalah sebagai pedoman dalam melaksanakan rencana kegiatan Subbag Rohjas pada setiap tahunnya, serta bertujuan untuk dijadikan bahan dalam mengambil kebijakan dan keputusan serta dijadikan bahan pelaporan.

Perencanaan pembinaan keIslāman ada di dalam perencanaan kegiatan Subbag Rohjas Bag Watpres Biro SDM Polda Jawa Barat. Subbag Rohjas sebagai salah satu unsur pelaksana dalam struktur organisasi 
khususnya pada Biro Sumber Daya Manusia Polda Jawa Barat mempunyai tugas dan tanggung jawab untuk merencanakan kegiatan pada setiap tahunnya guna mencapai sasaran yang maksimal. Dalam perencanaan di dalamnya menyangkut pendahuluan, perencanaan, pengorganisasian, pelaksanaan dan penutup dari semua kegiatan yang akan dilaksanakan Subbag Rohjas Biro SDM Polda Jabar.

Ruang lingkup dari rencana kegiatan Subbag Rohjas Bag Watpers Biro SDM mencangkup pembinaan mental rohani, pembinaan kesamptaan jasmani, pelayanan ijin ibadah keagamaan (Umroh, Haji dan Ibadah Keagamaan lainnya), dan pelayanan santunan dana catur cakti, serta proses ijin nikah dan cerai. Agar terlaksananya seluruh rangkaian kegiatan, sangat diperlukan perencanaan dan persiapan yang matang sebagai pedoman dalam pelaksanaan, hal yang perlu disiapkan dan direncanakan antara lain menyiapkan piranti lunak dan piranti keras, menyiapkan personil yang dilibatkan, menyiapkan sarana dan prasarana, serta pembagian tugas dan tanggung jawab personil Subbag Rohjas.

Dalam program pembinaan keagamaan, salah satunya terdapat program pembinaan keIslāman, adapun perencanaan yang dilakukan untuk program pembinaan keIslāman yang ada di Kepolisian Daerah Jawa Barat yang berdasarkan hasil wawancara dengan Paur Subbag Rohjas H. Ajat Sudrajat, S.Ag pada hari kamis, 03 September 2015 pukul 09.08 yang bertempat di Masjid Al-Amman Polda Jabar. Kegiatan program pembinaan keIslāman ada tiga yaitu:

1. Pembinaan Rohani Islām harian

Pembinaan rohani Islām harian dilakukan setiap ba'da żuhur, kegiatan ini terdiri dari żikir bersama dan kuliah tujuh menit. Pemateri dari pembinaan harian ini berasal dari dalam Polda Jawa Barat, yaitu dari seluruh satuan kerja yang ada di Polda Jawa Barat, setiap satker diperintahkan untuk menjadi panitia dan menyiapkan siapa yang akan menjadi pemateri untuk kegiatan pembinaan rohani Islām harian.

2. Pembinaan Rohani Islām Mingguan

Pembinaan rohani Islām mingguan ini dilakukan setiap hari kamis setelah apel, yaitu sekitar pukul 07.40 WIB dan selesai sekitar pukul 09.08 WIB. Pembinaan ini diisi oleh pemateri yang berasal dari luar kepolisian, yaitu ustaż atau kiai yang sudah tidak diragukan lagi kreadibilitasnya. Kegiatan ini diharapkan dapat membantu anggota dan PNS Polri untuk lebih mengenal Islām lebih dalam. Kegiatan pembinaan ini telah direncanakan jauh-jauh hari, telah ditentukan tema, waktu, dan jadwal pemateri untuk kegiatan selama satu tahun.

Pengurus pembinaan keIslāman, membuat perencanaan mengenai waktu, tempat, pemateri serta tema untuk pembinaan rohani Islām mingguan. Dalam pembinaan rohani Islām mingguan tema yang menentukan dari internal subbag rohjas.

3. Pembinaan Rohani Islām Hari Besar

Pembinaan rohani Islām hari besar adalah kegiatan pembinaan yang dilakukan untuk memperingati hari-hari besar Islām seperti Maulid Nabī, Isra Miraj', syafari ramaḍan, penyelanggaraan șalat Iḍul fitri \& Iḍul Aḍha, ibadah qurban, tahun baru Islām, dan hari jum'at Ketika pelaksanaan pembinaan rohani Islām hari besar audience tidak hanya dari anggota dan PNS Polri saja namun juga dihadiri oleh ibu-ibu bayangkhari.

\section{Pelaksanaan \\ KeIslāman}

Berdasarkan observasi yang telah dilakukan oleh peniliti pada tanggal 3 September 2015 sampai 7 Januari 2016 berikut ini adalah proses pelaksanaan pembinaan keIslāman di Kepolisian Daerah Jawa Barat:

1. Kegiatan Awal

Kegiatan awal diawali dengan pembukaan secara formal sesuai dengan Observasi Pembinaan KeIslāman Harian, Observasi Pembinaan KeIslāman Hari 
Besar Islam 1 dan 2, Observasi Pembinaan KeIslāman Mingguan 1 sampai dengan Observasi Pembinaan KeIslāman Mingguan 7. Pembukaan pada kegiatan awal dalam pembinaan rohani Islām harian yang dilaksanakan setiap hari ketika shalat żuhur sampai selesai diawali dengan mengucapkan salām, membaca basmallāh, membaca asmāul huusna sambil menunggu aẓan, shalat qabliyah żuhur. Sedangkan pembinaan rohani Islām mingguan dan perayaan hari-hari besar Islām dimulai dengan pengucapkan salām oleh panitia pembinaan yang biasa dipimpin oleh Ajat Sudrajat, S.Ag dan Dadan Ramdani, S.Ag., kemudian membaca basmallāh, membaca alfatihah, membaca surah yasin dan membaca asmāul ḥusna seluruh rangkaian pembukaan ini dipimpin atau dipandu oleh Ajat Sudrajat, S.Ag. dan Dadan ramdani, S.Ag.

\section{Kegiatan Inti}

Kegiatan yang dilakukan dalam kegiatan inti adalah pemberian materi tentang keIslāman, yang disampaikan oleh pemateri. Dalam pembinaan rohani Istām harian pematerinya berasal dari satuan kerja yang ada di Kepolisian Daerah Jawa Barat yang telah ditugaskan secara bergiliran setiap harinya. Sedangkan pemateri dalam pembinaan rohani Islām mingguan dan pembinaan rohani Islām hari besar pematerinya berasal dari luar Kepolisian Daerah Jawa Barat yaitu seorang kiai atau ustaż yang kondang, pemateri dalam pembinaan rohani Islām dan pembinaan rohani Islām hari besar juga berbeda-beda setiap pertemuannya.

Setelah materi selesai disampaikan, pemateri mengajak seluruh peserta pembinaan keIslāman untuk berdoa bersama. Di dalam kegiatan formal peserta tidak diberikan waktu untuk bertanya, namun peserta dapat menanyakan hal mengenai keIslāman secara personal setelah seluruh rangkaian pembinaan selesai.

Respon dari peserta yang mengikuti pembinaan keIslāman cukup antusias terhadap materi yang disampaikan.
Pembinaan keIslāman yang ada di Kepolisian Daerah Jawa Barat setiap pertemuannya memiliki tema materi dan metode penyampaian yang berbeda-beda.

3. Kegiatan Penutup

Pada kegiatan penutup pemateri mengajak seluruh peserta untuk membaca do'a, setelah itu pemateri mengembalikan kepada panitia pembinaan keIslāman. Pantia pembinaan keIslāman menginformasikan bahwa kegiatan pembinaan telah selesai, kemudian panitia mengajak para peserta untuk mengakhiri kegiatan dengan mengucapkan hamdallāh yang dilanjutkan dengan membaca do'a kafaratul majlis dan diakhiri dengan mengucapkan salām.
D. Faktor Pendukung dan Penghambat Pembinaan KeIslāman

1. Faktor Pendukung

Faktor pendukung dari program pembinaan keIslāman diantaranya adalah support dari pimpinan berupa ketauladanan , dana yang cukup dan dengan sarana prasarana yang disiapkan untuk kegiatan ini, sarana prasarana yang telah disiapkan berupa tempat pembinaan yaitu masjid, LED, microfon, infocus, buku yasin, Alquran dan terjemah, mukenah, meja kecil, hijab, sound system, $A C$, kipas angin papan informasi, dan sebagainya. Selain itu lembaga polri juga mewajibkan setiap anggota dan PNS Polri untuk mengikuti kegiatan pembinaan keIslāman. Selain itu faktor pendukung lainnya adalah dari setiap individu masing-masing anggota dan PNS Polri yang berada di Polda Jawa Bar itu sendiri, mereka telah memiliki kesadaran dalam diri mereka untuk mengikuti kegiatan pembinaan keIslāman yang diselanggarakan oleh Subbag Rohjas Biro SDM Polda Jawa Barat, sehingga kegiatan ini dapat diselenggarakan secara terusmenurus.

2. Faktor Penghambat

Pembinaan keIslāman yang diselenggarakan oleh Subbag Rohjas Biro SDM Polda Jawa Barat juga memiliki faktor penghambat, hambatan-hambatan 
tersebut diantaranya adalah pekerjaan yang tidak menentu dari masing-masing anggota, seperti harus tugas ke luar kantor, turun ke jalan bahkan ke luar wilayah, dan harus ada yang standby di ruangan untuk melayani masyarakat.

\section{E. Evaluasi dan Hasil Pembinaan KeIslāman}

1. Evaluasi Pembinaan KeIslāman

Evaluasi yang dilakukan untuk memperbaiki kegiatan pembinaan keIslāman ini berupa perencanaan kembali untuk menentukan panitia dan pemateri dalam pembinaan rohani Islām harian, dan penentuan jadwal, tema serta pemateri untuk pembinaan rohani Islām mingguan dan hari besar Islām untuk satu tahun kedepan. Perencenaan kembali ini dilihat dari faktor pendukung dan penghambat yang ada selama proses pembinaan keIslāman. Selain itu bentuk evaluasi juga dapat berupa laporan bulanan yang berisi dokumentasi, materi yang disampaikan, nama penceramah dan absensi kehadiran dari kegiatan pembinaan keIslāman ini. Laporan bulanan ini diserahkan kepada Kepala Kepolisian Daerah Jawa Barat, sedangkan laporan untuk seluruh satuan kerja yang ada di Polda Jawa Barat berupa akumulasi kehadiran dari setiap anggota masing-masing satker.

\section{Hasil Pembinaan KeIslāman}

Sedangkan hasil dari pembinaan keIslāman ialah semakin berkurangnya anggota dan PNS Polri di Kepolisian Daerah Jawa Barat yang melakukan penyimpangan atau melanggar kode etik. Hal ini sesuai dengan hasil studi dokumentasi yang dilakukan oleh peniliti.

\section{KESIMPULAN}

Berdasarkan hasil penelitian yang telah dijelaskan di atas, maka peneliti dapat melihat gambaran umum mengenai pembinaan keIslāman di Kepolisian Daerah Jawa Barat, oleh karena itu peneliti menarik kesimpulan bahwa secara keseluruhan pembinaan keIslāman di Kepolisian Daerah Jawa Barat cukup baik hal ini dilihat dari segi perencanaan, pelaksanaan dan evaluasi terhadap kegiatan pembinaan keIslāman di Kepolisian Daerah Jawa Barat. Namun, dalam pelaksanaan pembinaan keIslāman masih memeliki kekurangan, karena dalam pelaksanaan pembinaan keIslāman hanya dilakukan komunikasi satu arah.

\section{REFERENSI}

Arifin. (1985). Pokok-pokok Pikiran tentang Bimbingan dan Penyuluhan Agama. Jakarta: Bulan Bintang.

Bahasa, T. R. (2008). Kamus Besar Bahasa Indonesia Pusat Bahasa. Jakarta: PT Gramedia Pustaka Utama.

Baihaki, E. (2009). Dialektika Polisi, Masyarakat dan Komunikasi. Bandung: Unpad press.

Daradjat, Z. (2004). Ilmu Pendidikan Islam. Jakarta: Bumi Aksara.

Gafur, A. (1978). Pola Dasar Pembinaan dan Pengembangan Generasi Muda. Jakarta: Sekretariat Menteri Muda Urusan Pemuda Departemen Pendidikan dan Kebudayaan.

Jalaluddin. (2003). Teologi Pendidikan. Jakarta: RajaGrafindo Persada.

Kunarto. (1994). Police Deviance (Penyimpangan Polisi). Jakarta: Cipta Manunggal.

Kunarto. (1997b). Etika Polisi. Jakarta: PT. Cipta Manunggal.

Lihawa, R., \& Mustofa, M. (2010). Arah Kebijakan Polri 2010-2015. Jakarta: Komisi Kepolisian Nasional.

Sucipto, A. H., \& Arief, A. (2010). Terampil Mengolah Data Kualitatif dengan Nvivo. Jakarta: Kencana Prenada Media Group.

Syarif, R. (1991). Teknik Manajemen Latihan dan Pembinaan. Bandung: Angkasa. 